\title{
Determination of External Mass Transfer Model for Hydrolysis of Jatropha Oil Using Immobilized Lipase in Recirculated Packed-Bed Reactor
}

\author{
Chong-Wan Cheng $^{1}$, Rahmath Abdulla ${ }^{1}$, Rao Rampally Sridhar ${ }^{2}$ Pogaku Ravindra $^{{ }^{*}}$ \\ ${ }^{1}$ School of Engineering and Information Technology, University Malaysia Sabah, Kota Kinabalu, Malaysia \\ ${ }^{2}$ Chemical Engineering Department, Chaitanya Bharathi Institute of Technology, Hyderabad, India \\ E-mail: ${ }^{2}$ r ravindra@hotmail.com \\ Received August 11, 2011; revised August 26, 2011; accepted October 4, 2011
}

\begin{abstract}
In this study, a simple and effective technique for establishing an external mass transfer model in a recirculated packed-bed batch reactor (RPBBR) with an immobilized lipase enzyme and Jatropha oil system is presented. The external mass transfer effect can be represented with a model in the form of Colburn factor $J_{D}=$ $K \mathrm{Re}^{-(1-n)}$. The value of $K$ and $\mathrm{n}$ were derived from experimental data at different mass flow rates.The experiment shows an average increment of $1.51 \%$ FFA for calcium alginate and $1.62 \%$ FFA for carrageenan after the hydrolysis took place. Based on different biopolymer material used in immobilized beads, $J_{D}=$ $1.674 \mathrm{Re}^{-0.4}$ for calcium alginate and $J_{D}=1.881 \mathrm{Re}^{-0.3}$ for $k$-carrageenan were found to be adequate to predict the experimental data for external mass transfer in the reactor in the Reynolds number range of 0.2 to 1.2. The purposed model can be used for the design of industrial bioreactor and scale up. Besides, the external mass transfer coefficients for the hydrolysis of Jatropha oil reaction and the entrapment efficiency for the two biopolymer materials used were also investigated.
\end{abstract}

Keywords: Pseudomonas Cepacia Lipase, Jatropha curcas L. Oil, Carrageenan, Calcium Alginate, Hydrolsis, Packed Bed Reactor, Immobilized Enzyme, External Film Diffusion

\section{Introduction}

Lipases are one of the most significant enzymes that have been investigated for use in organic synthesis. Lipases can be used to modify lipid to produce synthetic lipids for various industrial applications. Lipase also has been used as biocatalyst for variety of other reactions such as hydrolysis of fats, synthesis of esters and glycerides. However, free lipase is not always sufficiently stable under operational condition and it is costly for one time usage. Thus, enzymes immobilization is introduced. Immobilization helps in elimination of enzyme recovery and purification process. Immobilized enzyme also can prevent protein contamination of the final product. Furthermore, immobilization helps to maintain constant environmental conditions so that it can protects the enzymes against changes in $\mathrm{pH}$ or temperature.

In this research, external mass transfer model of the system of immobilized lipase in Jatropha oil will be es- tablished. This model is important in designing an immobilized enzyme reactor as mass transfer limitation is one of the major concerns in utilization of immobilized lipase enzyme for industrial purposes [1]. Reactor design factors such as reactor types, size and operating conditions can be influenced by the external mass transfer in immobilized enzyme systems. In detail, for enzymatic reactions, the components from the bulk phase must be transferred to the catalytic surface and react on it. The rate-limiting step of the process can be the chemical reaction, but more frequently it will corresponds to transfer of the component to the catalyst surface. For this reason, the reactor size can be dictated by the mass-transfer processes rather than the kinetic processes. This fact alone justifies the importance of developing the mass transfer coefficient of the system. Understanding the model can also assist in controlling the global rate of a chemical process that takes place in the reactor. 


\subsection{Development of External Mass Transfer Model}

The external mass transfer model in the system of immobilized lipase enzyme in Jatropha oil will be established and the methodology is adapted from different journals [1].

A few assumptions are made as follows:

- The reaction follows a first-order rate.

- The reaction in a steady state condition.

- The flow in packed bed column is plug flow and has no axial dispersion.

- The immobilized enzyme particles are spherical.

- The enzyme activity throughout the particle is uniform.

\subsubsection{Apparent Reaction Rate}

The material balance for Jatropha oil (substrate) in the packed bed column is as follows:

$$
\left(\frac{H Q}{W}\right) \frac{\mathrm{d} C}{\mathrm{~d} Z} \times 6 \times 10^{-2}=-r
$$

where $r$ is the reaction rate $\left(\mathrm{mg} \cdot \mathrm{g}^{-1} \cdot \mathrm{h}^{-1}\right), Q$ is the volumetric flow rate $\left(\mathrm{ml} \cdot \mathrm{min}^{-1}\right), H$ is the height of the column $(\mathrm{cm}), W$ is the total amount of immobilized enzyme particles $(\mathrm{g})$, and $\mathrm{d} C / \mathrm{d} z$ is the concentration gradient along the column length $\left(\mathrm{mg} \cdot l^{-1} \cdot \mathrm{cm}^{-1}\right)$.

Assuming first-order kinetics, the reaction rate can be written in terms of bulk substrate concentration:

$$
\left(\frac{H Q}{W}\right) \frac{\mathrm{d} C}{\mathrm{~d} Z} \times 6 \times 10^{-2}=-k_{p} C
$$

where $k_{p}$ is the apparent first-order reaction rate constant $\left(1 \cdot \mathrm{g}^{-1} \cdot \mathrm{h}^{-1}\right)$ or the observed reaction rate constant and $C$ is the bulk substrate concentration $\left(\mathrm{mg} \cdot \mathrm{l}^{-1}\right.$ ).

For the boundary conditions 1 and 2, below:

Boundary condition 1: at $Z=0$ of $C=C_{i n}$ and

Boundary condition 2: at $Z=H$ of $C=C_{\text {out }}$

Equation (2) can be solved as follows:

$$
\ln \left(\frac{C_{\text {in }}}{C_{\text {out }}}\right)=\frac{W}{Q} \times k_{p} \times \frac{10^{2}}{6}
$$

where $C_{\text {in }}$ is the column inlet substrate (Jatropha oil) concentration $\left(\mathrm{mg} \cdot \mathrm{l}^{-1}\right)$ and $C_{\text {out }}$ is the column outlet substrate (Jatropha oil) concentration (mg. $\mathrm{l}^{-1}$ ).

The concentration at the outlet of the packed-bed is therefore can be written as:

$$
C_{\text {out }}=C_{\text {in }} \mathrm{e}^{-N}
$$

with $N$ defined as

$$
N=\frac{W}{Q} \times k_{p} \times \frac{10^{2}}{6}
$$

Since a recycling system is involved, the inlet conc entration to the column changes for every cycle. Ther efore, an overall mass balance for an RPBBR is as fol lows:

$$
\frac{\mathrm{d} V}{\mathrm{~d} t}=0
$$

where $V$ is the volume of the reacting solution in the reservoir ( $\mathrm{ml})$.

The component balance in the reservoir gives

$$
\frac{\mathrm{d} C_{1}}{\mathrm{~d} t}=-\frac{1}{\tau}\left(C_{2}-C_{1}\right)
$$

where $\tau$ is the residence time $(\mathrm{min})$ in the reservoir $(\mathrm{V} / \mathrm{Q}), C_{1}$ is the concentration of Jatropha oil $\left(\mathrm{mg} \cdot \mathrm{l}^{-1}\right)$ in the reservoir, and $C_{2}$ is the concentration $\left(\mathrm{mg} \cdot \mathrm{l}^{-1}\right)$ at the outlet of the packed-bed column to be circulated back to the reservoir.

Based on Equation (4), $C_{2}$ can be defined as follows:

$$
C_{2}=C_{1} \mathrm{e}^{-N}
$$

Combination of Equations (7) and (8) will give

$$
\frac{\mathrm{d} C_{1}}{\mathrm{~d} t}=-\frac{1}{\tau}\left(C_{1} \mathrm{e}^{-N}-C_{1}\right)
$$

Integrating Equation (9) using boundary conditions of $V=V_{\text {res }}$ and $C_{1}=C_{0}$ when $t=0$ gives the change of Jatropha oil concentration in the reservoir with time as

$$
C_{1}=C_{0} \exp \left[\frac{-\left(\mathrm{e}^{-N}-1\right) t}{\tau}\right]
$$

Based on Equation (10), a plot of $\ln \left(C_{1} / C_{0}\right)$ versus time will give a slope term as follows:

$$
\text { slope }=\frac{-\left(\mathrm{e}^{-N}-1\right)}{\tau}
$$

\subsubsection{Combination of Mass Transfer and Biochemical Reaction}

There are regions near the surface of the packing media where the fluid velocity is very low when fluid flows through a packed bed. In such regions around the exterior of packing media, the substrate transport takes place primarily by molecular diffusion.

The observed reaction rate can be significantly decreased by the external film diffusion since the rate may be very slow. The local rate of film diffusion of the Jatropha oil from the bulk fluid to the outer surface of the immobilized beads is influenced by the external mass transfer coefficient, the area for external mass transfer and the driving force for mass transfer (i.e. concentration difference between the bulk and the external surface of the immobilized bead). 


$$
r_{m}=k_{m} a_{m}\left(C-C_{s}\right)
$$

where $r_{m}$ is the external mass transfer rate of substrate $\left(\mathrm{mg} \cdot \mathrm{g}^{-1} \cdot \mathrm{h}^{-1}\right), k_{m}$ is the external mass transfer coefficient $\left(\mathrm{cm} \cdot \mathrm{h}^{-1}\right), a_{m}$ is the external surface area for mass transfer $\left(\mathrm{cm}^{2} \cdot \mathrm{mg}^{-1}\right), C$ is the substrate concentration in the bulk liquid $\left(\mathrm{mg} \cdot \mathrm{L}^{-1}\right)$, and $C_{s}$ is the substrate concentration at surface of the immobilized cell $\left(\mathrm{mg} \cdot \mathrm{L}^{-1}\right)$.

The value of $a_{m}$ can be determined using the following equation

$$
a_{m}=\frac{6}{\rho_{p} d_{p}}
$$

With $d_{p}$ as the particle diameter $(\mathrm{cm})$ and $\rho_{p}$ the particle density $\left(\mathrm{mg} \cdot \mathrm{cm}^{-3}\right)$.

The first-order biochemical reaction rate of immobilized beads can be written as:

$$
r=k C_{s}
$$

$k$ is the "surface" first-order reaction rate constant $\left(1 \cdot \mathrm{g}^{-1} \cdot \mathrm{h}^{-1}\right)$ which takes into account both the effective internal mass transfer and the intrinsic reaction.

The effective internal mass transfer coefficient can be assumed constant at low substrate concentration. As the substrate concentrations used in this study were low, Equation (14) is valid throughout this study [1].

At steady state, the rates of external mass transfer and overall substrate utilization by the particle will be the same; Equations (12) and (14) are equated and rearranged to give

$$
C_{s}=\frac{k_{m} a_{m} C}{k+k_{m} a_{m}}
$$

Substituting Equation (15) into (14) and equating with $r=k_{p} C$, the effects of external mass transfer on the apparent reaction rate constant, $k_{p}$ is shown as follow:

$$
k_{p}=\frac{k k_{m} a_{m}}{k+k_{m} a_{m}}
$$

or

$$
\frac{1}{k_{p}}=\frac{1}{k}+\frac{1}{k_{m} a_{m}}
$$

\subsubsection{Empirical Model}

The value of $\mathrm{k}$ is constant as far as this particular reaction is concerned and is independent of the operating parameters such as the mass flow rate and the scale of the system. However, the external mass transfer coefficient, $k_{m}$ changes with parameters such as flow rate, reactor diameter and fluid properties. This in turn changes the apparent reaction rate.

Therefore, the external mass transfer coefficient $\left(k_{m}\right)$ can be expressed in terms of operational parameters and the properties on the fluid by the dimensionless group:

$$
J_{D}=\frac{k_{m} P}{G}\left(\frac{\mu}{\rho D_{f}}\right)^{\frac{2}{3}}=K(\mathrm{Re})^{n-1}
$$

where $J_{D}$ is the Colburn factor and Re is the Reynolds number. The symbols $\mu, \rho$ and $D_{f}$ are the fluid viscosity $\left(\mathrm{g} \cdot \mathrm{cm}^{-1} \cdot \mathrm{min}^{-1}\right)$, density $\left(\mathrm{g} \cdot \mathrm{ml}^{-1}\right)$ and diffusivity $\left(\mathrm{cm} \cdot \mathrm{min}^{-1}\right)$, respectively. The value of $\mathrm{n}$ depends on the mass transfer conditions and varies from 0.1 to 1.0 depending on the flow characteristics.

$G$ is the mass flux $\left(\mathrm{g} \cdot \mathrm{cm}^{-2} \cdot \mathrm{min}^{-1}\right)$ and it can be calculated using Equation (19) as follows:

$$
G=\frac{Q \rho}{a_{c} \varepsilon}
$$

where $Q$ is the volumetric flow rate $\left(\mathrm{ml} \cdot \mathrm{min}^{-1}\right), a_{c}$ is the cross-sectional area of column $\left(\mathrm{cm}^{2}\right)$ and $\varepsilon$ is the void fraction in a packed-bed.

Equating Equation (18), the external mass transfer coefficient can be expressed as:

$$
k_{m}=\frac{K}{\rho}\left(\frac{\mu}{\rho D_{f}}\right)^{\frac{-2}{3}}\left(\frac{d_{p}}{\mu}\right)^{n-1} G^{n}
$$

or

$$
k_{m}=A G^{n}
$$

where

$$
A=\frac{K}{\rho}\left(\frac{\mu}{\rho D_{f}}\right)^{\frac{-2}{3}}\left(\frac{d_{p}}{\mu}\right)^{n-1}
$$

By substituting Equation (21) into Equation (17):

$$
\frac{1}{k_{p}}=\left(\frac{1}{A a_{m}}\right)\left(\frac{1}{G^{n}}\right)+\frac{1}{k}
$$

The plot $1 / k_{p}$ vs $1 / G^{n}$ for different values of $n$ yields straight lines with slope $\left(1 / A a_{m}\right)$ and intercept $(1 / k)$. The calculated values of A and $k$ from the graph are then used to get the values of $k_{m}$ (using Equation. (21)) and an estimated $k_{p}$ (using Equation (17)). A trial-and-error procedure is repeated for all $\mathrm{n}$ values until the estimated value of $k_{p}$ matches well with the experimental $k_{p}$ [1-3].

\section{Materials and Method}

\subsection{Materials}

The non-edible crude Jatropha oil is produced in laboratory using solvent extraction method and it is stored at low temperature to avoid rancidity of the vegetable oil. Pseudomonas cepacia lipase is obtained from Amano 
Enzyme (Japan) where it is used throughout the experiment. Biopolymer materials such as carrageenan and sodium alginate powder are purchased from FMC Biopolymer (USA). N-Hexane is of analytical grade and is purchased from Fisher Scientific (USA).

\subsection{Extraction of Jatropha Oil from Jatropha Seed}

$100 \mathrm{~g}$ of Jatropha seed is dried and the shells of the seeds are removed. The seed are then ground to fine powder to increase the efficiency of oil extraction using n-hexane. The Jatropha powder is taken into extractor column. Solvent $n$-hexane is filled in the solvent vessel. The extraction is done at temperature of $110^{\circ} \mathrm{C}-130^{\circ} \mathrm{C}$ for $5-7$ hours. After extraction completed, the round bottom flask containing $n$-hexane and extracted Jatropha oil is transferred to rotary evaporator to further evaporate the solvent. The final extracted Jatropha oil is inserted in air-tight bottle which is covered by aluminum foil and kept in the refrigerator to prevent Jatropha oil from deterioration by temperature, sunlight and presence of air. The recovered n-hexane solvent may be reused for subsequent extractions to prevent wastage [4].

\subsection{Entrapment of Lipase in Calcium Alginate Beads}

$1 \mathrm{~g}$ lipase powder/ml phosphate buffer $\mathrm{pH} 7$ is mixed with $100 \mathrm{ml}$ sodium alginate solution $(1 \%-2 \%$, w/v). The mixture is stirred thoroughly to ensure complete mixing. As soon as the mixed solution dripped into $2 \%$ of $\mathrm{CaCl}_{2}$ solution with a syringe, calcium-alginate beads are formed. The $\mathrm{CaCl}_{2}$ solution is constantly stirred with magnetic stirrer to avoid sticking between the dropped beads. The bead size can be changed by using syringes with different needle diameters. After $20 \mathrm{~min}$ of hardening, the beads are separated from the $\mathrm{CaCl}_{2}$ solution and are stored at temperature below $4^{\circ} \mathrm{C}$ to minimize enzyme leakage.

\subsection{Entrapment of Lipase in $\boldsymbol{k}$-Carrageenan Beads}

$1 \mathrm{~g}$ lipase powder/ml phosphate buffer $\mathrm{pH} 7$ will be mixed in $100 \mathrm{ml} \kappa$-carrageenan solution $(1 \%-2 \%, \mathrm{w} / \mathrm{v})$. The mixture will be stirred thoroughly to ensure complete mixing. During the mixing, the mixture should be maintained at $35^{\circ} \mathrm{C}-40^{\circ} \mathrm{C}$ to prevent early hardening of $k$-carrageenan solution. As soon as the mixed solution dripped into $2 \%$ of $\mathrm{KCl}$ solution with a syringe, the beads will formed. The bead size can be changed by using syringes with different needle diameters. After 20 min of hardening, the beads will be separated from the $\mathrm{KCl}$ solution and are stored at temperature below $4^{\circ} \mathrm{C}$ to minimize enzyme leakage [5].

\subsection{Entrapment Efficiency}

The samples are mixed well and $1.0 \mathrm{ml}$ of the samples is transferred to a $10 \mathrm{ml}$ glass tube. $1.4 \mathrm{ml}$ of Lowry solution is added to the tubes. The tubes are capped and mixed. All the tubes are incubated for 20 minutes at room temperature in dark. The diluted Folin reagent is prepared. After 20 minutes of incubation, the samples are added $0.2 \mathrm{ml}$ of diluted Folinreagent to each tube. Again, the samples are mixed and incubated for more than 30 minutes at room temperature in dark. After 30 minutes, the samples are transferred to semi-micro disposable cuvettes and tested by vis-spectrophotometer at $600 \mathrm{~nm}$ [6].

\subsection{Hydrolysis of Jatropha Oil in RPBBR}

The batch stirred-tank reactor is heated with heater and is stirred using a magnetic stirrer. A peristaltic pump was installed in batch reactor to form a recirculated packedbed batch reactor (RPBBR) as shown at Figure 1.

The reaction mixture is prepared in proportion of 15 $\mathrm{ml}$ of Jatropha oil, $24 \mathrm{ml}$ of $\mathrm{n}$-hexane, $1.2 \mathrm{ml}$ of water. The mixture is incubated at $40^{\circ} \mathrm{C}$ and stirred at $200 \mathrm{rpm}$. Immobilized lipase is packed into jacketed column. Samples are taken at different time intervals and analyzed for fatty acids.

\subsection{Chemical Titration for Fatty Acid Concentration}

$1 \mathrm{~g}$ sample of oil is dissolved into about $20 \mathrm{ml}$ of mixture

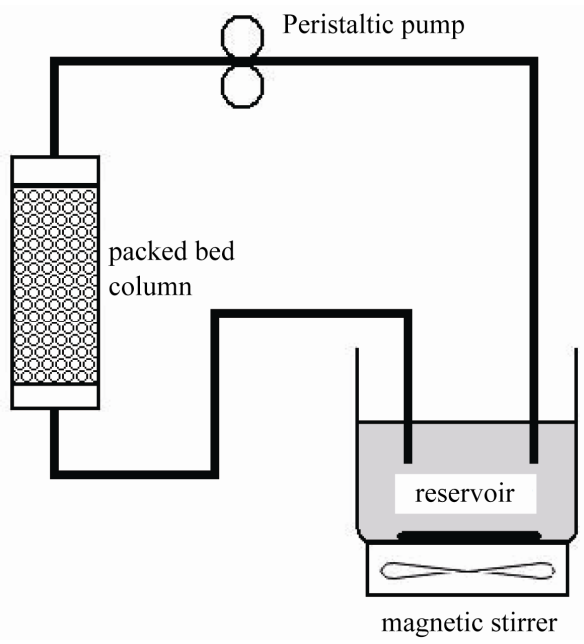

Figure 1. Schematic representation of a recirculated packedbed batch reactor. 
of solvent ethanol and diethyl ether. Few drops of phenolphthalein indicator solution are added into the mixture. The mixture of solution is titrated immediately with sodium hydroxide solution. The mixture is well mixed by stirring with magnetic stirrer. It is important to titrate the mixture to the same intensity of pink color as observed. The amount of sodium hydroxide solution used is recorded. Lastly, percentage of free fatty acid is calculated using formula: [7]

$$
\begin{aligned}
\% \text { FFA }= & \frac{\text { Vtitrant }(\text { mlsoln })}{1000} \times \frac{N \text { moles } \mathrm{NaOH}}{1(\text { Lsoln })} \times \\
& \frac{1 \text { mole FFA }}{1 \text { mole } \mathrm{NaOH}} \times \frac{282.46 \mathrm{~g} \text { FFA }}{1 \text { mole } F F A} \times \frac{1}{\text { weightofoil }(\mathrm{g})}
\end{aligned}
$$

\section{Results and Discussion}

\subsection{Solvent Extraction of Jatropha Seed}

From $100 \mathrm{~g}$ of seed, approximately 70 to $75 \mathrm{ml}$ of oil will be extracted. For the extracted oil, the oil will be kept in refrigerator and away from sunlight to prevent further reaction.

\subsection{Capsule Size of Entrapped Lipase}

The air-dried calcium alginate beads and $k$-carrageenan beads with immobilized lipase are almost spherical in shape. The average diameter of calcium alginate bead and $k$-carrageenan beads are $0.3 \mathrm{~cm}$.

\subsection{Surface Morphologies of Entrapped Lipase}

As can be observed from the SEM diagram, the two different biopolymer materials used show a different structure on the surface of the beads which may caused by the different cross linking that took place in respective beads. From observation, there are white spherical dots located at everywhere of the beads for both parameters ( $k$-carrageenan and calcium alginate). They are presumed as the lipase enzyme.

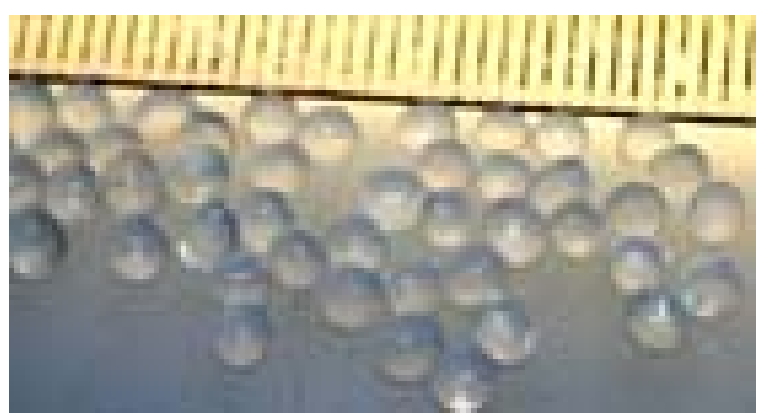

Figure 2. Picture of entrapped lipase.

\subsection{Entrapment Efficiency}

The entrapment efficiencies of respective mixture were determined in terms of protein coupling. From data in Table 1, the entrapment efficiencies were found to be $87.25 \%$ and $67.45 \%$ for calcium alginate and $k$-carrageenan respectively.

This studies show that there is loss of enzymes. This was confirmed by the protein assay performed on the aqueous phase (hardening solution). Some of the possible reasons are the difference of structure of respective biopolymer material.

Besides, presence of agitation in collection flask may cause the loss of enzyme.

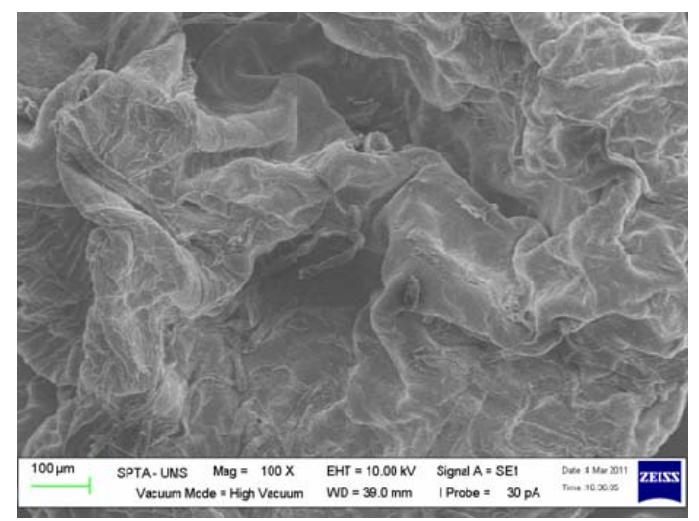

(a)

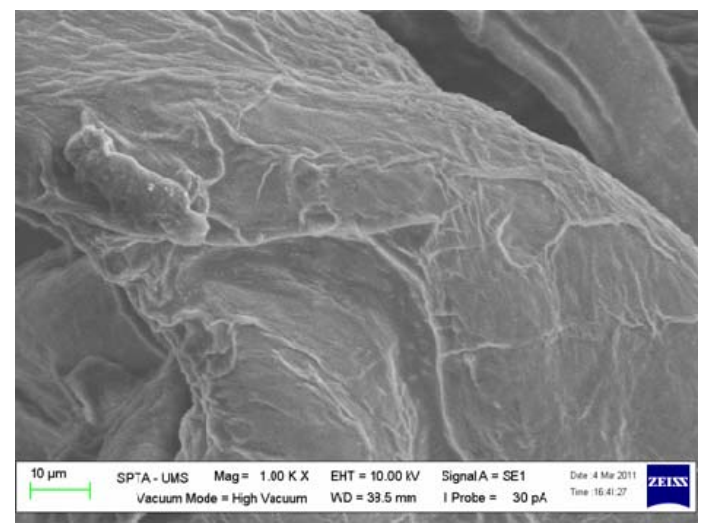

(b)

Figure 3. SEM of calcium alginate beads (a) at $100 \times$ magnification (b) at $1000 \times$ magnification.

Table 1. Entrapment efficiency of immobilized lipase.

\begin{tabular}{ccccc}
\hline & \multicolumn{2}{c}{ Calcium alginate } & \multicolumn{2}{c}{$k$-Carrageenan } \\
\cline { 2 - 5 } & $\begin{array}{c}\text { First } \\
\text { run }\end{array}$ & $\begin{array}{c}\text { Second } \\
\text { run }\end{array}$ & $\begin{array}{c}\text { First } \\
\text { run }\end{array}$ & $\begin{array}{c}\text { Second } \\
\text { run }\end{array}$ \\
\hline $\begin{array}{c}\text { Amount of protein } \\
\text { introduced }\left(\mathrm{mg} \cdot \mathrm{ml}^{-1}\right)\end{array}$ & 114.615 & 114.615 & 114.615 & 114.615 \\
$\begin{array}{c}\text { Amount of protein } \\
\text { coupled }\left(\mathrm{mg} \cdot \mathrm{ml}^{-1}\right)\end{array}$ & 96.923 & 103.077 & 73.846 & 80.769 \\
$\begin{array}{c}\text { Protein coupling yield }(\%) \\
\text { Average }(\%)\end{array}$ & 84.56 & 89.93 & 64.43 & 70.47 \\
\hline
\end{tabular}




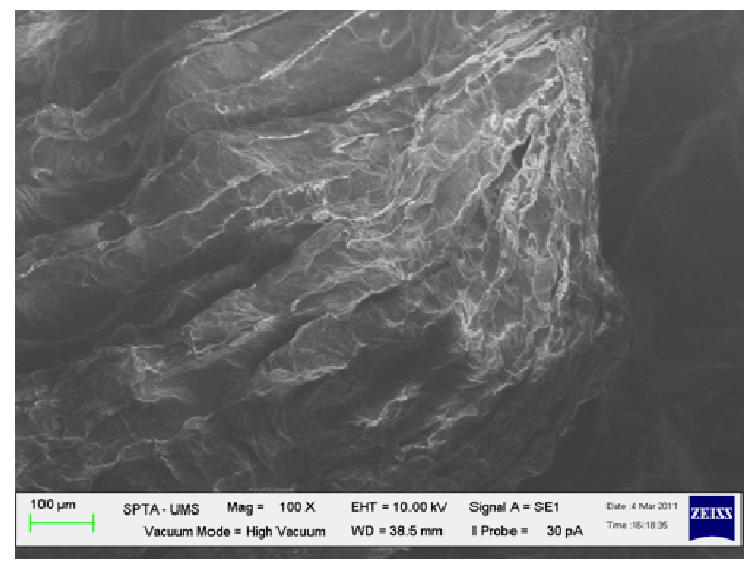

(a)

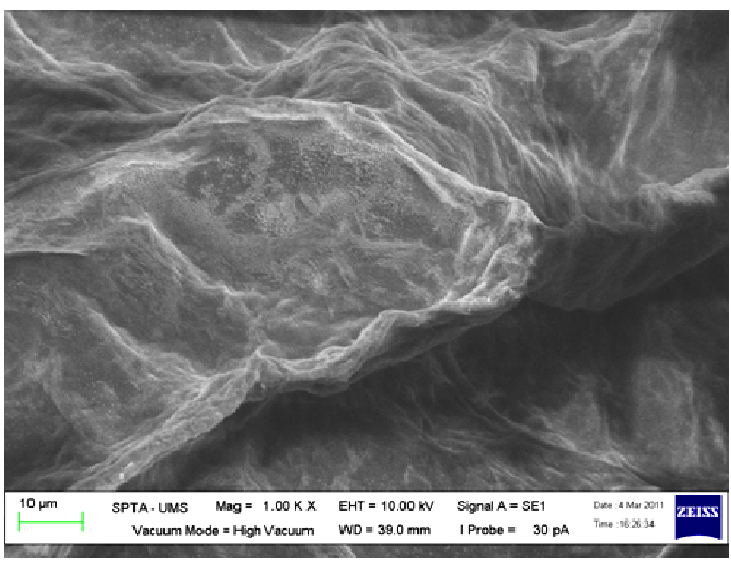

(b)

Figure 4. SEM of carrageenan beads (a) at $100 \times$ magnification (b) at $1000 \times$ magnification.

\subsection{Establishment of External Mass Transfer Model}

The figures below show the hydrolysis profile of Jatropha oil in the recirculated packed-bed batch reactor at various flow rates. It can be observed that the concentration of fatty acid with respect with time is in increasing trend for both parameters. This shows that the hydrolysis of triglycerides took place. Different increment of fatty acid concentration is due to the different flow rate applied.

From the experimental data of concentration of fatty acid, $\ln C_{1} / C_{0}$ as a function of time at different flow rates is plotted and is shown in Figures 7 and 8.

The slope of each line was determined and used to calculate the value of $\mathrm{N}$ for respective flow rate.

The value of $k_{p}$, the observed first-order reaction rate constant, was obtained for each flow rate based on $\mathrm{N}$ value. The calculated values of $k_{p}$ are listed in Table 2 . For both parameter, it can be observed that as flow rateincreases, the value of $k_{p}$ decrease. This trend is possi-

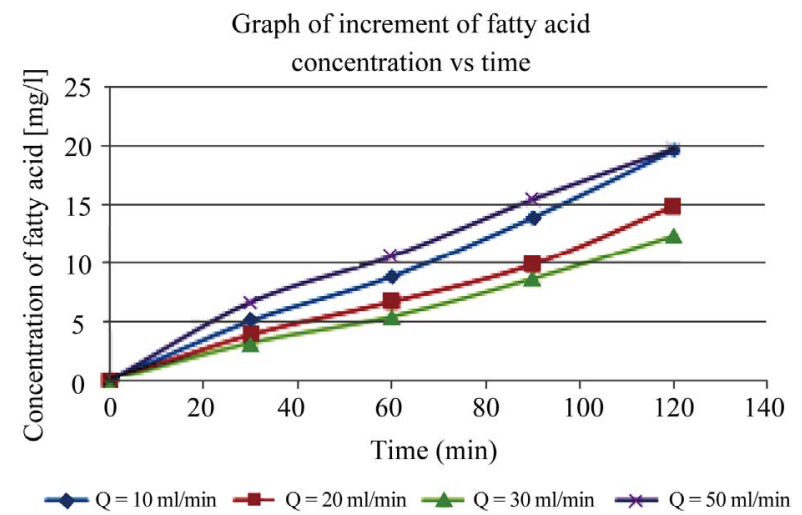

Figure 5. Increment of fatty acid concentration against time by calcium alginate parameter.

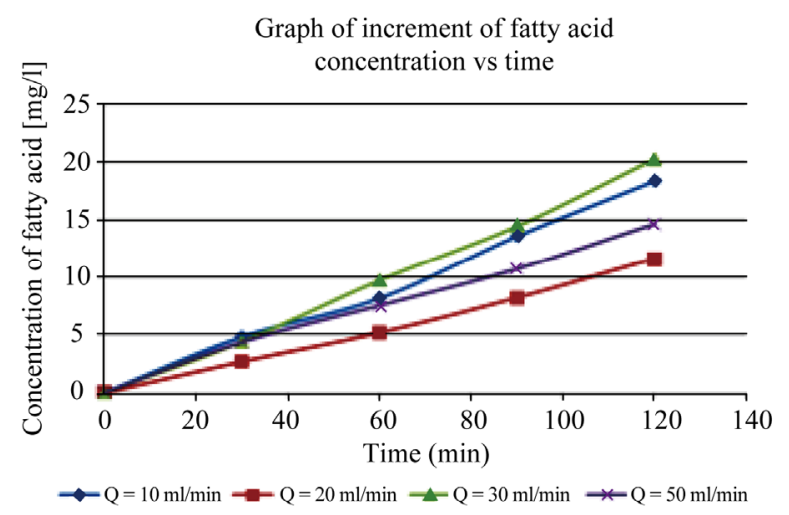

Figure 6. Increment of fatty acid concentration against time by $k$-carrageenan parameter.

ble when it is attribute to low residence time at high flow rate [8], which affect the diffusion of solute to pores of particle and may have increase short circuiting inside the reactor. The trend low residence time at high flow rate can be observed at Table 2.

Referring to Equation (23), a plot of the experimentally measurable quantity of $1 / k_{p}$ against $1 / G^{n}$ should yield a straight line of slope 1/A $a_{m}$ and intercept $1 / \mathrm{k}$ with values of $\mathrm{n}$ ranging from 0.1 to 1.0 . This range of

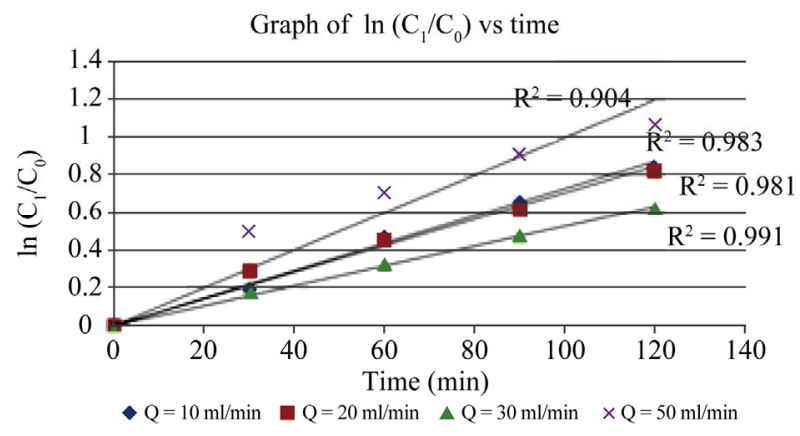

Figure 7. Plot of $\ln \left(C / C_{0}\right)$ vs time to estimate number of transfer unit for calcium alginate parameter. 


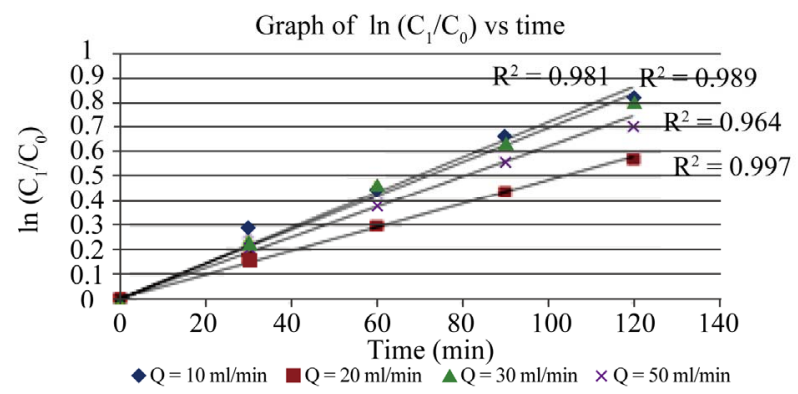

Figure 8. Plot of $\ln \left(C / C_{0}\right)$ vs time to estimate number of transfer unit for $k$-carrageenan parameter.

value has encompassed all the exponential values in the Colburn-Chilton factor that have been presented in the literature [1].

A few plots of $1 / k_{p}$ against $1 / G^{n}$ (for $\mathrm{n}$ values of 0.1 , 0.3, 0.6 and 1.0) are shown in Figure 9. It was found that all values of $\mathrm{n}$ show a similar trend; with increasing $1 / G^{n}$ value, the $1 / k_{p}$ value is decreasing.

All $\mathrm{n}$ values were analyzed further to determine the value of $\mathrm{n}$ that gives the best film diffusional model in predicting mass transfer limitations. Using the slope and intercept of each plot, the values of $\mathrm{k}$ and A were calculated. With Equation (21), the value of $k_{m}$ at each flow rate was estimated. Based on the calculated $k$ and $k_{m}$, a value of $k_{p}$ was recalculated and was compared with the $k_{p}$ found experimentally.

The most satisfactory model is based on the $\mathrm{n}$ value which provides the closest $k_{p}$ as compared to the experimental results would be by using the calculation of normalized percent deviation. The percent deviation of the calculated values and the experimental results for all flow rates for parameter calcium alginate are shown in Table 3 for $n=0.1,0.3,0.6$ and 1.0. According to Table 3 , model having an exponent of 0.6 has the lowest normalized percent deviation which is $0.036 \%$.

Therefore, a model having an exponent of 0.6 would provide satisfactory predictions of the external mass transfer coefficients in immobilized lipase system for parameter alginate. Steps are repeated for parameter $k$-carrageenan and it was found the most satisfactory $\mathrm{n}$ value is 0.7 with normalized percent deviation of $0.0043 \%$ as shown in Table 4 .

$$
\Delta \%=\frac{\sum_{N}^{i=1} \frac{k_{\text {pexperiment }}-k_{\text {pcalculation }}}{k_{\text {pexperiment }}}}{N} \times 100
$$

Calculation of constant of Colburn factor is done by using McCune and Wilhelm equation as shown at below. This correlation has been proven by Rovito and Kittel to be effective in predicting diffusion in immobilized enzyme in packed bed reactors.

$$
J_{D}=1.625 \mathrm{Re}^{-0.507}
$$

Table 2. Observed first-order reaction rate constant, $k_{p}$ at different flow rate.

\begin{tabular}{cccc}
\hline \multirow{2}{*}{$\begin{array}{c}\text { Flow rate } \\
\left(\mathrm{ml} \cdot \mathrm{min}^{-1}\right)\end{array}$} & $\begin{array}{c}\text { Residence time } \\
(\mathrm{min})\end{array}$ & $\begin{array}{c}\text { Calcium } \\
\text { Alginate }\end{array}$ & $k$-Carrageenan \\
\cline { 3 - 4 } & & $k_{p}$ & $k_{p}$ \\
\hline 10 & 24.12 & 0.005725 & 0.004947 \\
20 & 12.06 & 0.005368 & 0.002756 \\
30 & 8.04 & 0.003520 & 0.004713 \\
50 & 6.43 & 0.01130 & 0.004116 \\
\hline
\end{tabular}

Table 3. The percent deviation of calculated values of $\boldsymbol{k}_{p}$ from experimental values at different $\mathbf{n}$ for calcium alginate parameter.

\begin{tabular}{cccccc}
\hline $\begin{array}{c}\mathrm{Q} \\
\left(\mathrm{ml} \cdot \mathrm{min}^{-1}\right)\end{array}$ & $\begin{array}{c}\text { Experimental } \\
k_{p}\end{array}$ & \multicolumn{4}{c}{ Percent deviation (\%) } \\
\cline { 2 - 6 } & 0.005725 & -0.0812 & -0.0717 & -0.0587 & -0.0441 \\
10 & 0.005368 & -0.0149 & -0.0114 & -0.0076 & -0.0045 \\
20 & 0.003520 & -0.4444 & -0.4557 & -0.4704 & -0.4864 \\
30 & 0.01130 & 0.5387 & 0.5373 & 0.5352 & 0.5326 \\
50 & & & & &
\end{tabular}

Table 4. The percent deviation of calculated values of $\boldsymbol{k}_{p}$ from experimental values at different $n$ for $k$-carrageenan parameter.

\begin{tabular}{cccccc}
\hline Q & Experimental & \multicolumn{4}{c}{ Percent deviation (\%) } \\
\cline { 3 - 6 }$\left(\mathrm{ml} \cdot \mathrm{min}^{-1}\right)$ & $k_{p}$ & $n=0.1$ & $n=0.4$ & $n=0.7$ & $n=1.0$ \\
\hline 10 & 0.004947 & 0.2039 & 0.1914 & 0.1771 & 0.1616 \\
20 & 0.002756 & -0.4244 & -0.4278 & -0.4288 & -0.4277 \\
30 & 0.004713 & 0.1691 & 0.1736 & 0.1790 & 0.1846 \\
50 & 0.004116 & 0.5092 & 0.0624 & 0.0725 & 0.0808 \\
Average value of deviation (\%) & -0.0124 & -0.0124 & -0.0043 & -0.0165 \\
\hline
\end{tabular}

with $J_{D}$ is the Colburn factor; Re is the Reynolds number.

Reynolds number is calculated with respect of different flow rate. Thus Colburn factor and $\mathrm{k}$ constant with respect to different flow rate can be calculated as well using Equation (18).

Thus the proposed external mass transfer model for Jatropha oil in entrapped lipase (calcium alginate) system is $J_{D}=1.674 \mathrm{Re}^{-0.4}$

And the proposed external mass transfer model for Jatropha oil in entrapped lipase ( $k$-carrageenan) system is $J_{D}$ $=1.881 \mathrm{Re}^{-0.3}$.

\subsection{Determination of Mass Transfer Coefficient}

Mass transfer coefficient can be calculated based of equation below:

$$
k_{m}=\frac{J_{D} G}{\rho N_{S C}^{2 / 3}}
$$

where $J_{D}$ is the Colburn factor; $\mathrm{G}$ is the is the superficial velocity $\left(\mathrm{cm} \cdot \mathrm{min}^{-1}\right) ; \rho$ is the density of the oil $\left(\mathrm{g} \cdot \mathrm{ml}^{-1}\right)$ and $N_{s c}$ is the Schmidt number. 

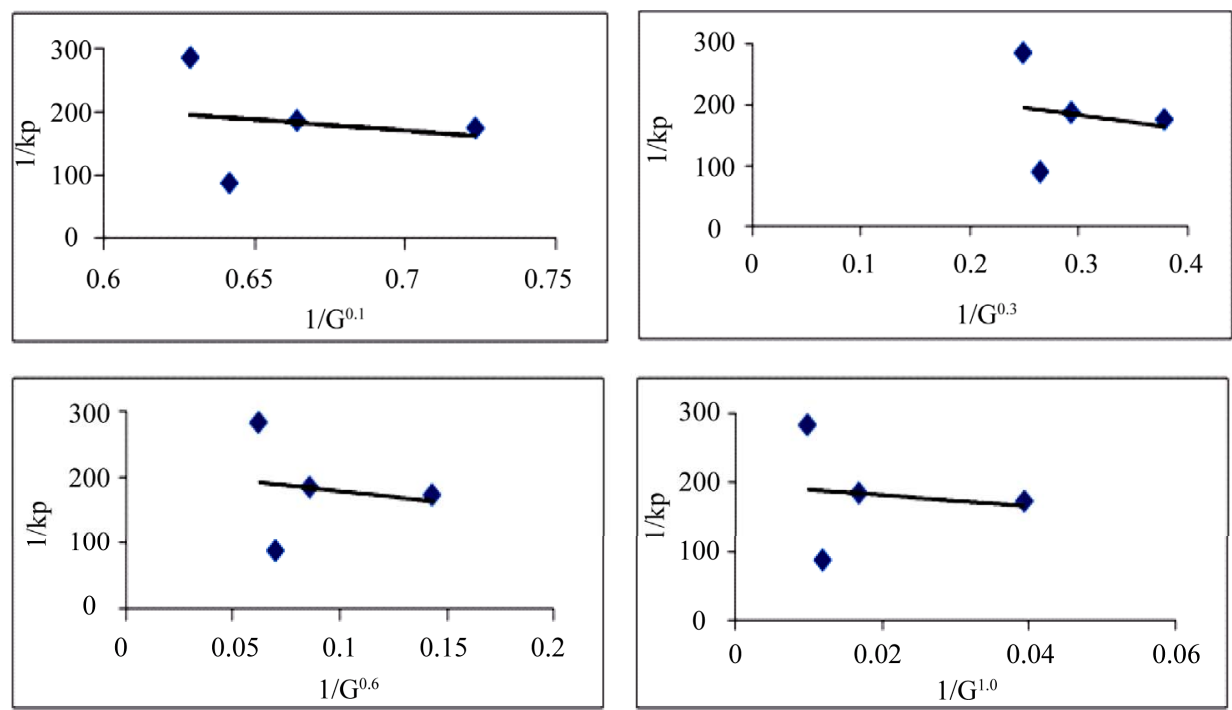

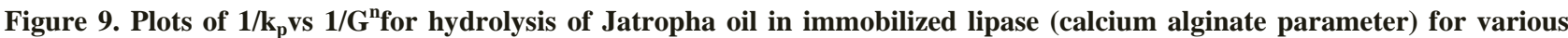
value of $n$. (a) $n=0.1$; (b) $n=0.3$; (c) $n=0.6$; (d) $n=1.0$.
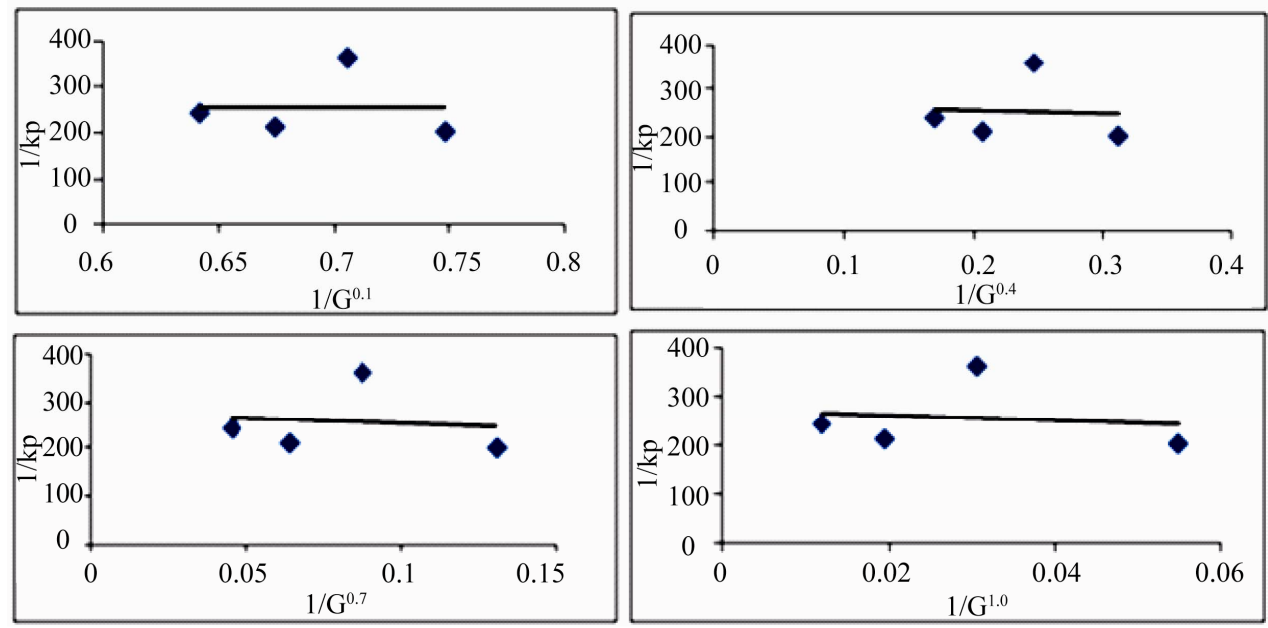

Figure 10. Plots of $1 / k_{\mathrm{p}} \mathrm{vs} 1 / \mathrm{G}^{\mathrm{n}}$ for hydrolysis of Jatropha oil in immobilized lipase (k-carrageenan parameter) for various value of $n$. (a) $n=0.1$; (b) $n=0.4$; (c) $n=0.7$; (d) $n=1.0$.

It can be observed that with increasing flow rate, generally the external mass transfer rate and the difference of substrate concentrate is in decreasing trend. This can be explain due to low retention time (proven by experimental data) with increase of flow rate, the external mass transfer is slowed down and reduced the external mass transfer rate. In other words, diffusion limitation is predominant in the external film of the immobilized beads. Thus, for higher flow rate, the mass transfer at the external film is slower and caused the concentration difference between surface and bulk liquid to be lower.

\section{Conclusions}

A mass transfer model in terms of dimensionless num- bers and experimental data plays important roles in design and simulation of a bioreactor performance. Usage of enzymes in industrial applications are gaining popularity due to the milder operating condition, lesser undesirable side products, better wastewater qualities and other advantages. However, usage of free enzyme is not economical feasible. Immobilization of enzyme will not only increase stability of enzyme, also encourage enzyme recycle thus reduce production cost. Selection of suitable immobilization matrix is important to ensure effective usage of enzyme and sustainability.

In this study, two biopolymer material; alginate and $k$ carrageenan are investigated in term of entrapment efficiency and external mass transfer. Alginate shows a higher value which is $87.25 \%$ than $k$-carrageenan; $67.45 \%$ 
Table 5. Calculation of constant $\mathrm{K}$ for (a) calcium alginate (b) $k$-carrageenan.

\begin{tabular}{ccccc}
\hline $\begin{array}{c}\mathrm{Q} \\
\left(\mathrm{ml} \cdot \mathrm{min}^{-1}\right)\end{array}$ & $\begin{array}{c}\mathrm{Gexp} \\
\left(\mathrm{cm} \cdot \mathrm{min}^{-1}\right)\end{array}$ & $\mathrm{Re}$ & $J_{D}$ & $\mathrm{~K}$ \\
\hline Alginate & & & & \\
10 & 25.5274 & 0.3254 & 2.8709 & 1.8323 \\
20 & 59.9967 & 0.7648 & 1.8615 & 1.6722 \\
30 & 103.6616 & 1.3215 & 1.4107 & 1.5772 \\
50 & 84.5124 & 1.0774 & 1.5647 & 1.6120 \\
& & & Average & 1.674 \\
Carrageenan & & & & \\
10 & 18.2880 & 0.2331 & 3.3998 & 2.1966 \\
20 & 32.6306 & 0.4159 & 2.5349 & 1.9485 \\
30 & 51.2991 & 0.6539 & 2.0153 & 1.7743 \\
50 & 83.8545 & 1.0690 & 1.5709 & 1.6026 \\
& & & Average & 1.881 \\
\hline
\end{tabular}

Table 6. Comparison of concentration difference between the external film (a) calcium alginate (b) $k$-carrageenan.

\begin{tabular}{ccccc}
\hline $\mathrm{Q}\left(\mathrm{ml} \cdot \mathrm{min}^{-1}\right)$ & $\begin{array}{c}r_{m} \\
\left(\mathrm{mg} \cdot \mathrm{g}^{-1} \cdot \mathrm{min}^{-1}\right)\end{array}$ & $\begin{array}{c}a_{m} \\
\left(\mathrm{~cm}^{2} \cdot \mathrm{mg}^{-1}\right)\end{array}$ & $\begin{array}{c}k_{m} \\
\left(\mathrm{~cm} \cdot \mathrm{min}^{-1}\right)\end{array}$ & $\begin{array}{c}(\mathrm{C}-\mathrm{Cs}) \\
\left(\mathrm{mg} \cdot 1^{-1}\right)\end{array}$ \\
\hline Alginate & & & & \\
10 & 0.000838 & 15.1971 & $3.0418 \times 10^{-06}$ & 18.1349 \\
20 & 0.000747 & 15.9128 & $4.6355 \times 10^{-06}$ & 10.1361 \\
30 & 0.000713 & 16.4517 & $6.0699 \times 10^{-06}$ & 7.1413 \\
50 & 0.000558 & 15.2955 & $5.4885 \times 10^{-06}$ & 6.6562 \\
Carrageenan & & & & \\
10 & 0.000560 & 13.2958 & $2.5806 \times 10^{-06}$ & 16.3311 \\
20 & 0.000316 & 12.4852 & $3.4332 \times 10^{-06}$ & 7.3943 \\
30 & 0.000579 & 12.8299 & $4.2911 \times 10^{-06}$ & 10.5273 \\
50 & 0.000410 & 12.6894 & $5.4674 \times 10^{-06}$ & 5.9205 \\
\hline
\end{tabular}

in term of entrapment efficiency. There are two models presented to describe the mass transfer of substrate in hydrolysis of Jatropha oil by immobilized lipase in a recirculated packed-bed batch reactor. Based on the analyses, $J_{D}=1.674 \mathrm{Re}^{-0.4}$ for alginate and $J_{D}=1.881$ $\mathrm{Re}^{-0.3}$ for carrageenan were found to be adequate to predict the experimental data for external mass transfer in the reactor in the Reynolds number range of 0.2 to 1.2 .

\section{Acknowledgements}

The Authors are thankful to the authorities of School of Engineering and Information Technology, University
Malaysia Sabah for the support in carrying out the research work.

\section{References}

[1] Y. H. Chew, T. L. Chew, M. R. Sarmidi, R. A. Aziz and F. Razali, "External Mass Transfer Model for the Hydrolysis of Palm Olein Using Immobilized Lipase," Food and Bioproducts Processing, Vol. 86, No. 4, 2008, pp. 276-282. doi:10.1016/i.fbp.2008.02.001

[2] N. Dizge and B. Tansel, "External Mass Transfer Analysis for Simultaneous Removal of Carbohydrate and Protein by Immobilized Activated Sludge Culture in a Packed Bed Batch Bioreactor," Journal of Hazardous Materials, Vol. 184, No. 1-3, 2010, pp. 671-677. doi:/10.1016/j.jhazmat.2010.08.090

[3] T. Murugesan and R. Y. Sheeja, "A Correlation for the Mass Transfer Coefficients during the Biodegradation of Phenolic Effluents in a Packed Bed Reactor," Separation and Purification Technology, Vol. 42, No. 2, 2005, pp. 103-110. doi:10.1016/j.seppur.2004.06.008

[4] M. Y. Liauw, F. A. Natan, P. Widiyanti, D. Ikasari, N. Indraswati and F. E. Soetaredjo, "Extraction of Neem oil (Azadirachta Indica A. Juss) Using N-Hexane and Ethanol: Studies of Oil Quality, Kinetic and Thermodynamic," ARPN Journal of Engineering and Applied Sciences, Vol. 3, No. 3, 2008, pp. 49-54.

[5] P. D. Desai, A. M. Dave and S. Devi, "Entrapment of Lipase into $k$-Carrageenan Beads and Its Use in Hydrolysis of Olive Oil in Biphasic System," Journal of Molecular Catalysis B: Enzymatic, Vol. 31, No. 4-6, 2004, pp. 143-150. doi:10.1016/j.molcatb.2004.08.004

[6] O. H. Lowry, N. J. Rosebrough, A. L. Farr and R. J. Randall, "Protein Measurement with the Folin-Phenol Reagents," The Journal of Biological Chemistry, Vol. 193, No. 1, 1951, pp. 265-275.

[7] American Oil Chemists' Society, "AOCS Official Method Ca5a-40, Free Fatty Acid," Champaign, III, 1993.

[8] M. N. Kathiravan, R. K. Rani, R. Karthick and K. Muthukumar, "Mass Transfer Studies on the Reduction of $\mathrm{Cr}$ (VI) Using Calcium Alginate Immobilized Bacillus sp. In Packed Bed Reactor," Bioresource Technology, Vol. 101, No. 3, 2010, pp. 853-858. doi:/10.1016/j.biortech.2009.08.088 


\section{Nomenclatures}

\begin{tabular}{ll}
$a_{c}$ & cross-sectional area of column \\
$a_{m}$ & external surface area for mass transfer \\
$C$ & bulk substrate concentration \\
$C_{1}$ & concentration of Jatropha oil in the reservoir \\
$C_{2}$ & concentration at the outlet of the packed-bed column to be \\
$C_{\text {in }}$ & circulated back to the reservoir \\
$C_{\text {out }}$ & column inlet substrate (Jatropha oil) concentration \\
$C s$ & column outlet substrate (Jatropha oil) concentration \\
$\mathrm{d} C / \mathrm{d} z$ & substrate concentration at surface of the immobilized cell \\
$D_{f}$ & concentration gradient along the column length \\
$d_{p}$ & diffusivity \\
$G$ & particle diameter \\
$H$ & mass flux \\
$J_{D}$ & height of the column \\
$k$ & Colburn factor \\
$k_{m}$ & "surface" first-order reaction rate constant \\
$k_{p}$ & external mass transfer coefficient \\
$Q$ & apparent first-order reaction rate constant \\
$r$ & volumetric flow rate \\
$\operatorname{Re}$ & reaction (substrate consumption) rate \\
$r_{m}$ & Reynolds number \\
$\tau$ & external mass transfer rate of substrate \\
$V$ & residence time in the reservoir \\
$W$ & volume of the reacting solution in the reservoir \\
$\varepsilon$ & total amount of immobilized enzyme particles \\
$\rho$ & void fraction in a packed-bed \\
$\rho_{p}$ & fluid viscosity \\
& particle density \\
\hline &
\end{tabular}

